\title{
ANALISIS HAMBATAN TARIF DAN NON TARIF SERTA PENGEMBANGAN PASAR EROPA PADA PRODUK PERIKANAN INDONESIA
}

\section{ANAL YSIS OF TARIFF AND NON-TARIFF BARRIERS AND DEVELOPMENT OF EUROPEAN MARKET IN INDONESIAN FISHERY PRODUCTS}

\author{
Dian Dwi Laksani dan Kumara Jati \\ Badan Pengkajian dan Pengembangan Perdagangan, Kementerian Perdagangan,
}

\begin{abstract}
Abstrak
Analisis hambatan tarif dan non tarif serta pengembangan pasar Eropa pada produk perikanan Indonesia penting dalam rangka meningkatkan akses pasar serta mempromosikan dan membangun image untuk pengembangan ekspor ke negara-negara di Eropa. Penelitian ini menganalisis tentang deskripsi umum tentang sektor perikanan di Indonesia yang terdapat potensi untuk penetrasi pasar ke Eropa. Tarif Uni Eropa berkisar antara 0-21\% di antara negaranegara potensial lainnya. Kebijakan non tarif dirasakan mulai memberatkan pemerintah dan pengusaha perikanan yaitu terkait standar mutu dan pangan dengan basis perlindungan konsumen tingkat tinggi. Analisis Export Product Dynamic (EPD) di pasar Uni Eropa menunjukkan sebanyak 165 produk perikanan Indonesia di posisi rising star (winner in increasing market), 18 produk pada posisi lost opportunity (loose market opportunity), 14 produk pada posisi winner in declining market. Diharapkan pemerintah maupun pengusaha perikanan mampu mengetahui dengan cepat perkembangan isu perdagangan diantaranya dengan mengakses fasilitas helpdesk on-line yang dikeluarkan Uni Eropa untuk membantu negara mitra dagang dalam mengakses informasi mengenai pasar Uni Eropa.
\end{abstract}

Kata kunci: hambatan tarif dan non tarif, pengembangan pasar Eropa, produk perikanan Indonesia, Export Product Dynamic (EPD)

\begin{abstract}
Analysis of tariff and non-tariff barriers and development of European market in Indonesian fishery products is important in order to improve market access, to promote and build image for export development to European countries. This study analyzes general description of fishery sector in Indonesia that is potential for market penetration to Europe. European Union (EU) tariffs range from 0-21\% among other potential countries. Non-tariff policy concerning quality and food standards for high levels consumer protection is considered burdening the government and fisheries entrepreneurs. Analysis of Export Product Dynamics (EPD) in the EU market shows 165 Indonesian fishery products in rising star position (winner in increasing market), 18 products in lost opportunity, and 14 products in winner position in declining market. The government and fishery entrepreneurs are expected to quickly understand the development of trade issues, for instance by accessing the help desk facility on-line issued by the European Union to assist trading partner countries in accessing information about the EU market.
\end{abstract}

Keywords: tarif and non-tarif barriers, European market development, Indonesian fishery products, Export Product Dynamic (EPD) 


\section{A. Pendahuluan}

Secara bilateral, hubungan Indonesia dengan negara-negara anggota Uni Eropa (UE) / European Union (EU) sudah terjalin lama sebelum UE menandatangani kerjasama antar kawasan dengan Association of the Southeast Asian Nations (ASEAN) tahun 1980. Baik UE maupun Indonesia mempunyai perwakilan tetap di ibu kota masing-masing yang menunjukkan besarnya kepentingan dan perhatian antara kedua pihak. Momentum peningkatan hubungan ekonomi secara signifikan terjadi pada November 2009 ketika Indonesia dan UE menandatangani Framework Agreement on Comprehensive Partnersip and Cooperation (PCA). Pada tahun 2010-2011, kedua pihak juga melakukan kajian bersama tentang perdagangan dan investasi yang dirangkum dalam Report of the EUIndonesia Vision Group on Trade and Investment Relations yang diumumkan pada tanggal 28 Juni 2011 di hadapan Komisioner Perdagangan UE Karel de Gucht dan Duta Besar Indonesia di Brussels. Rekomendasi utama dari laporan tersebut adalah perlunya UE dan Indonesia untuk segera memulai negosiasi menuju Comprehensive Economic Partnership Agreement (CEPA).

Sejak Perjanjian Maastrich 1992, UE merupakan salah satu kekuatan ekonomi dan politik dunia. Institusi regional ini terdiri dari 28 negara dengan perbedaan tingkat ekonomi yang cukup mencolok, dapat dilihat dari Luxemburg yang pada tahun 2010 pendapatan per kapita penduduknya paling tinggi hingga Bulgaria yang paling rendah yaitu kurang lebih 1/6 Luxemburg (Eurostat, 2015). Namun demikian secara umum, UE merupakan salah satu kekuatan ekonomi dunia. Walaupun sedang dilanda krisis keuangan sejak tahun 2009 (terutama di 17 negara yang tercakup dalam Eurozone), UE merupakan mitra yang penting bagi Indonesia. Data yang dikeluarkan European Commission / EC (2010) menunjukkan bahwa sejak tahun 2009 Indonesia adalah sasaran Official
Development Assistance (ODA) terbesar kedua EU di Asia setelah Afganistan. Jumlah penduduk yang lebih dari 511,4 juta jiwa pada tahun 2014 (CIA, 2015) dan dengan daya beli yang tinggi, UE adalah pasar yang sangat kuat karena mempunyai GDP per kapita tahun 201 sebesar USD 34.500 (CIA, 2015). Data Trademap (2015) menyebutkan bahwa UE di tahun 2013 merupakan mitra dagang Indonesia keempat setelah Jepang, China dan Singapura. Data tersebut memperlihatkan masih kecilnya volume perdagangan UEIndonesia dewasa ini dibandingkan dengan potensi keduanya.

Indonesia masuk ke dalam 15 besar negara dengan jumlah tangkapan ikan terbesar dan Benua Eropa merupakan benua dengan jumlah tangkapan ikan terbesar. Benua lainnya yang masuk 3 besar yaitu Asia dan Amerika. Belanda menjadi negara Eropa dengan jumlah tangkapan ikan terbesar sebanyak 5 juta ton di tahun 2014 (Euromonitor, 2015). Hal ini merupakan peluang bagi Indonesia untuk pengembangan produk perikanan di Eropa.

Uni Eropa yang merupakan pasar potensial bagi ekspor hasil perikanan Indonesia memiliki kebijakan atau peraturan dengan standar tersendiri yang cukup tinggi, baik dalam hal tarif maupun jaminan kualitas dan keamanan produk pangan, termasuk di dalamnya produk perikanan. Hal ini menjadi tantangan bagi Indonesia dalam memenuhi permintaan konsumen sebagai salah satu cara memposisikan diri agar tetap kompetitif selain juga tetap bersaing dengan negara kompetitor. Kenyataan tersebut tentunya menunjukkan bahwa kebijakan yang diterapkan dalam perdagangan internasional dapat menjadi hambatan bagi ekspor Indonesia, baik itu dalam hal tarif maupun non tarif.

Tarif untuk ikan di Uni Eropa terikat dengan World Trade Organization (WTO), tarif bound MFN (Most Favored Nations) merepresentasikan tarif EU yang maksimum (Ur, 2014). Secara umum, tingkat tarif yang diberlakukan oleh Uni Eropa 
paling tinggi dibandingkan dengan negaranegara maju lainnya seperti Jepang dan Amerika Serikat (Dahuri, 2002). Tarif bea masuk yang tinggi nantinya akan meningkatkan harga produk yang beredar di pasar. Selain itu, UE memberlakukan adanya diskriminasi tarif. Negara-negara bekas jajahan UE mendapatkan keringanan atau dibebaskan dari kewajiban membayar tarif bea masuk. Hal tersebut semakin melemahkan daya saing ekspor Indonesia dibandingkan dengan negara eksportir lainnya. Selain tarif, hambatan non-tarif di UE juga penting untuk dibahas. Hambatan nontarif yaitu semua ukuran yang mempengaruhi kondisi perdagangan internasional, termasuk kebijakan dan regulasi yang menghambat dan memfasilitasi perdagangan (Fugazza, 2017).

Hal-hal tersebut di atas baik yang bersifat hambatan tarif maupun non tarif akan berpengaruh terhadap ekspor produk perikanan Indonesia. Selain itu UE menjadi potensi pasar produk perikanan Indonesia. Untuk itu perlu dianalisis hambatan perdagangan tarif maupun non tarif yang dikeluarkan oleh UE, daya saing serta strategi untuk pengembangan pasar UE.

Painte (2008) telah melakukan riset terkait dengan pengaruh hambatan tarif dan non tarif di Pasar Eropa tetapi spesifik untuk komoditas udang. Pendekatan yang dilakukan dengan regresi variabel dummy non tarif, tarif dan lag ekspor kurun waktu 1992-2006. Ditemukan bahwa kebijakan non tarif berpengaruh positif terhadap volume ekspor udang Indonesia dan tarif berpengaruh negatif.

Berbeda dengan Painte (2008), Kee et al. (2004) lebih khusus menjelaskan tentang elastisitas permintaan impor dan distorsi perdagangan. Ditemukan bahwa sebenarnya kebijakan non tarif yang lebih mengikat dapat mendistorsi impor. Negara-negara di dunia rata-rata $30 \%$ lebih tertutup dibandingkan dengan tarif rata-rata impor mereka.

Penelitian terbaru dari Pusparani (2015) tentang dampak implementasi kebijakan keamanan pangan terhadap produk perikanan Indonesia menyatakan bahwa keamanan makanan adalah bagian dari Sanitary and Phytosanitary Standards (SPS) yang bertujuan memproteksi kesehatan manusia. Selain itu ternyata ditemukan kebijakan keamanan pangan tidak berpengaruh terhadap ekspor perikanan Indonesia ke UE dan Amerika Serikat.

Berdasarkan latar belakang tersebut, belum banyak penelitian terbaru yang dilakukan terkait dengan hambatan tarif dan non tarif di pasar Eropa khusus untuk produk perikanan. Maka dari itu untuk mengisi kekosongan tersebut, kami melakukan penelitian yang bertujuan untuk melihat bagaimana hambatan tarif dan non tarif serta bagaimana pengembangan pasar Eropa pada produk perikanan Indonesia.

\section{B. Metode Penelitian}

Jenis data yang digunakan dalam analisis ini meliputi data sekunder, yang bersumber dari BPS (2015), Trademap (2015), UNComtrade (2015), dan WITS. Metode analisis yang digunakan yaitu model Constant Market Share Analysis (CMSA). Model diterapkan untuk mengetahui faktor yang mempengaruhi pertumbuhan ekspor komoditas produk perikanan. Variabel yang diukur adalah:

1. Peningkatan pada konsumsi impor negara tujuan ekspor (World Demand Effect)

2. Komposisi ekspor negara A ke negara B (Product Effect)

3. Perubahan daya saing (Competitiveness Effect)

$\mathrm{X}_{(\mathrm{t})}-\mathrm{X}_{(0)}=\underbrace{\mathrm{mX}_{(0)}}_{\text {World Demand Effect }}+\underbrace{\operatorname{SUM}\left\{\left(\mathrm{m}_{\mathrm{i}}-\mathrm{m}\right) \mathrm{X}_{\mathrm{i}(0)}\right\}}_{\text {Product Effect }}+\underbrace{\mathrm{SUM}\left\{\mathrm{X}_{\mathrm{i}(\mathrm{t})}-\mathrm{X}_{\mathrm{i}(0)}-\mathrm{m}_{\mathrm{i}} \mathrm{X}_{\mathrm{i}(0)\}}\right\}}_{\text {Competitiveness Effect }}$

$X_{(t)}$ nilai ekspor pada tahun $t ; X_{(0)}$ nilai ekspor pada tahun $0, m$ adalah pertumbuhan untuk total nilai ekspor, $m_{i}$ adalah pertumbuhan ekspor komoditas i. $X_{i(t)}$ adalah nilai ekspor komoditas i pada tahun $t . X_{i(0)}$ adalah nilai ekspor komoditas $i$ pada tahun 0 . 
Pendekatan Export Product Dynamics (EPD) digunakan untuk mengidentifikasi keunggulan kompetitif suatu produk dan mengukur posisi pasar dari produk suatu negara untuk tujuan pasar tertentu. Pendekatan ini juga untuk mengetahui apakah suatu produk merupakan produk dengan performa yang dinamis atau tidak. EPD dianalisis ke dalam 4 kategori yaitu rising star, falling star, lost opportunity, dan retreat.

\section{Pembahasan}

\section{Perdagangan Indonesia dengan UE}

Secara umum, perdagangan perikanan antara Indonesia dengan UE mengalami peningkatan dari tahun ke tahun. Ekspor Indonesia ke UE tahun 2010 hingga 2014 tercatat bertutut-turut sebesar US\$ 116,91 juta; US\$ 217,21 juta; US\$ 383,87 juta; US\$ 484,95 juta; US\$ 522,10 juta. Impor Indonesia dari UE cenderung stabil yaitu tahun 2010 hingga 2014 tercatat US\$ 27,35 juta; US\$ 37,86 juta; US\$ 39,34 juta; US\$ 46,87 juta; US\$ 60,51 juta (Trademap, 2015). Tren yang positif ini menyebabkan neraca perdagangan perikanan dari tahun ke tahun terus mengalami peningkatan, yaitu US\$ 89,56 juta; US\$179,35 juta; US\$ 344,52 juta; US\$ 438,08 juta; dan US\$ 461,59 juta.

Sektor perikanan UE paling besar ditopang oleh impor dari Norwegia. Pada tahun 2014, UE mengimpor perikanan sebesar US\$ 8.135 juta atau sekitar 13\% dari seluruh ekspor perikanan UE. Impor terbesar UE berturutturut berasal dari Norwegia, Belanda, Jerman, Spanyol, dan Denmark. Posisi Indonesia sendiri berada pada peringkat ke-28 atau sekitar $1 \%$ dari total impor perikanan UE. Ekspor Indonesia ke UE masih tertinggal oleh negara ASEAN lainnya seperti Vietnam dan Thailand yang masing-masing menduduki peringkat ke-15 dan ke-19. UE mengimpor perikanan dari Vietnam sebesar US\$ 1.305 juta atau sekitar $2 \%$ dari seluruh impor perikanan Jepang. Sementara Thailand sebesar US\$ 1.040 juta atau $2 \%$ pada tahun 2014. Meskipun Indonesia masih tertinggal oleh Thailand dan Vietnam, ekspor Indonesia masih dominan terhadap ekspor perikanan Filipina, Myanmar dan Malaysia.

\section{Gambar 1. Kinerja Perdagangan di Sektor Perikanan Indonesia dengan Uni Eropa Tahun 2010 - 2014 (US\$ Juta)}

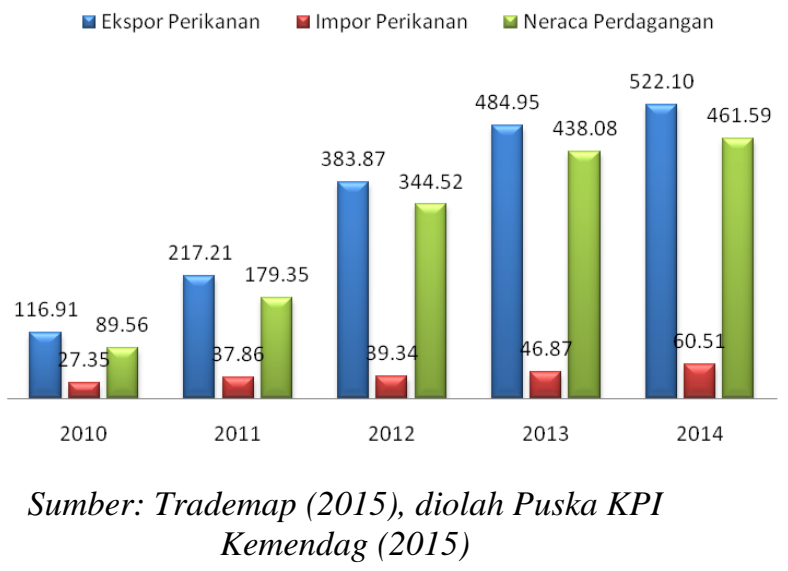

Gambar 2. Impor Sektor Perikanan Uni Eropa berdasarkan Negara, 2014

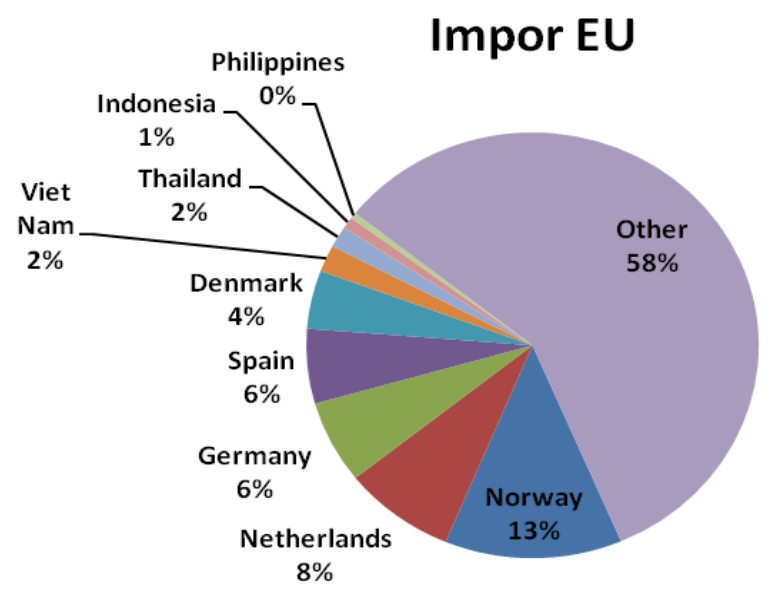

Sumber: Trademap (2015), diolah Puska KPI Kemendag (2015)

\section{Perkembangan Sektor Perikanan di UE}

Sektor perikanan di pasar Uni Eropa diproyeksikan tumbuh dengan kecepatan tetap. Pertumbuhan tergantung pada sejumlah faktor, termasuk kepercayaan konsumen dalam produk yang mereka 
beli dan makan. Pasar ikan dan seafood di UE sedang menghadapi tantangan, termasuk labelling, isu-isu lingkungan dan ekologi, keselamatan konsumen keselamatan, dan kekhawatiran tentang kualitas. Mengingat bahwa ikan dan makanan laut relatif mahal jika dibandingkan dengan daging sapi dan unggas, isu-isu ini menjadi penting, terutama ketika situasi ekonomi yang lemah membuat konsumen lebih diskriminatif tentang di mana dan bagaimana untuk menghabiskan uang mereka.

Dalam dekade terakhir ini, ikan dan makanan laut mulai mendapatkan perhatian yang lebih positif mengenai manfaat kesehatan, yaitu kandungan Omega 3 asam lemak yang memiliki sejumlah kelebihan, salah satunya adalah kemampuan untuk meningkatkan kadar high density lipoprotein (HDL), atau "kolesterol baik." Manfaat kesehatan ditambah dengan manfaat lain bahwa ikan rendah kalori dan sangat dianjurkan oleh kelompok dokter dan organisasi medis serta organisasi gizi dan diet serta adanya tren terbaru di UE yaitu keinginan untuk makan lebih alami, didorong oleh minat yang kuat konsumen dalam makan sehat, pelestarian lingkungan, dan sumber daya yang lebih berkelanjutan ditunjang oleh daya beli yang kuat, cenderung mempengaruhi pasar terhadap permintaan ikan dan seafood.

\section{Ukuran (Market Size) Pasar Perikan- an}

Pasar utama Ikan dan seafood di UE adalah Spanyol, Perancis, Jerman, Italia, Swedia, Inggris (UK), dan Belanda. Spanyol merupakan pasar terbesar untuk ikan dan seafood di Uni Eropa, dan merupakan importir terbesar ke empat ikan dan makanan laut di dunia (Euromonitor, 2013). Di tahun 2012 impor spanyol untuk ikan dan seafood turun menjadi USD 5.287,14 juta, tetapi angka itu tidak berpengaruh besar, Spanyol tetap menjadi salah satu pasar ikan dan seafood dunia.
Tabel 1.

Pasar Ikan dan Seafood di Uni Eropa berdasarkan Negara (Juta USD)

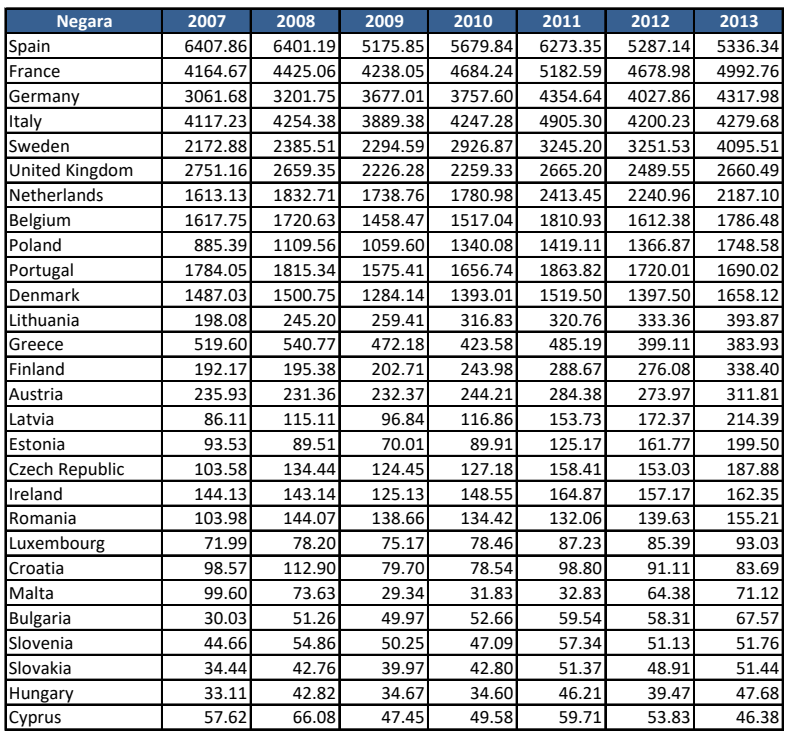

Sumber: TradeMap, 2013

Penjualan ikan dan makanan laut di UE terus meningkat, berdasarkan data Euromonitor (2013). Penjualan ikan segar tertinggi di negara Spanyol tahun 2017 dengan jumlah 1.341,70 ribu ton. Empat negara lainnya yaitu Inggris, Jerman, Italia, dan Portugal juga mengalami tren penjualan yang positif.

\section{Tren Konsumsi}

Pada tahun 2012, konsumsi produk perikanan per kapita di Jerman, Polandia dan Perancis berada di bawah $10 \mathrm{~kg}$ per tahun, sedangkan di Portugal mencapai $50 \mathrm{~kg}$ per tahun. Jenis produk perikanan yang diminta bervariasi, tergantung pada negara, misalnya di Eropa Selatan, berbagai spesies produk perikanan tersedia dibandingkan dengan Eropa Utara yang lebih terbatas. Di Jerman, misalnya, jenis Alaska pollock, herring, salmon dan tuna mendominasi $60 \%$ dari konsumsi produk perikanan secara keseluruhan, sedangkan di Spanyol dan Perancis, empat jenis tersebut dikonsumsi hampir sepertiga dari seluruh penjualan. 
Tabel 2.

Penjualan Ikan Segar dan Makanan Laut per Negara (Kg Per Kapita)

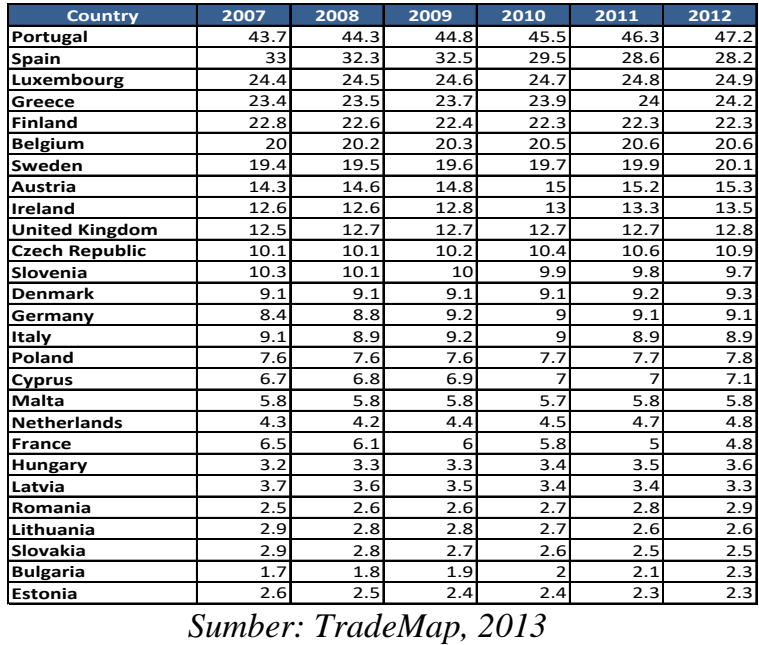

Contoh yang lain, untuk negaranegara Mediterania, ikan yang disukai adalah ikan yang masih utuh dan segar sedangkan di pasar Eropa utara, lebih menyukai ikan yang telah diproses dan dikemas. Dari sisi perdagangan, UE semakin tergantung pada impor ikan dan seafood untuk memenuhi kebutuhannya. Pada 2013, UE mengimpor ikan dan produk perikanan lainnya mencapai lebih dari USD 37,29 milyar, sedangkan ekspornya hanya USD 22,3 milyar di tahun 2013. Akibatnya, defisit neraca perdagangan UE untuk ikan dan makanan laut mencapai USD 14,66 milyar. Adapun jenis yang paling banyak diimpor adalah produk segar untuk salmon, udang dan tuna.

\section{Kekuatan, Kelemahan, Hambatan Dan Peluang Kerja Sama Indonesia- Uni Eropa di Sektor Perikanan}

Pemerintah Indonesia memiliki strategi yang berkaitan dengan sektor makanan laut dalam kebijakan industrialisasi. Industrialisasi kelautan dan perikanan adalah proses untuk peningkatan sistem produksi yang hasilnya untuk meningkatkan nilai tambah kapasitas, produktivitas dan skala produksi produk perikanan. Hal ini didu- kung oleh kebijakan terpadu antara pembangunan infrastruktur, iklim usaha dan investasi, pengetahuan, teknologi dan sumber daya manusia untuk kesejahteraan masyarakat.

Tabel 3.

Ekspor Indonesia ke UE untuk produk Ikan

\begin{tabular}{|c|c|c|c|c|c|c|c|c|}
\hline \multirow[b]{2}{*}{$\mathrm{N}$} & \multirow{2}{*}{ Produk kan } & \multicolumn{5}{|c|}{ Juta USD } & \multirow{2}{*}{ Tren } & \multirow{2}{*}{$\begin{array}{l}\text { Growth } \\
16 / 15\end{array}$} \\
\hline & & 2012 & 2013 & 2014 & 2015 & 2016 & & \\
\hline & Frozen shrimps and prawns, even smoked, whethe & 46.19 & 60.60 & 72.33 & 61.53 & 52.45 & 2.73 & -14.76 \\
\hline & Octopus "Octopus spp.", smoked, frozen, dried, sa & 30.23 & 17.67 & 26.68 & 28.40 & 28.50 & 3.64 & 0.36 \\
\hline & Cuttle fish "Sepia officinalis, Rossia macrosoma, $\mathrm{S}$ & 19.13 & 14.81 & 17.75 & 17.91 & 23.73 & 6.40 & 32.47 \\
\hline & \begin{tabular}{|l|l|} 
Frozen fish fillets, n.e.s. & \\
\end{tabular} & 5.91 & 4.26 & 6.40 & 8.41 & 13.02 & 25.35 & 54.88 \\
\hline & Frozen swordfish "Xiphias gladius" & 3.73 & 6.29 & 6.14 & 8.13 & 12.55 & 30.76 & 54.38 \\
\hline & Frozen fillets of swordfish "Xiphias gladius" & 6.97 & 21.50 & 14.99 & 16.64 & 11.02 & 6.83 & -33.78 \\
\hline & Frozen fillets of tilapia "Oreochromis spp." & 10.32 & 10.83 & 12.27 & 9.40 & 10.50 & -1.08 & 11.75 \\
\hline & Frozen albacore or longfinned tunas "Thunnus alal & 1.89 & 10.53 & 1.75 & 9.21 & 10.44 & 38.85 & 13.35 \\
\hline & \begin{tabular}{|l||} 
Frozen fish, n.e.s. \\
\end{tabular} & 5.67 & 7.89 & 7.93 & 7.09 & 8.30 & 6.78 & 17.07 \\
\hline & Frozen fish meat n.e.s. (excluding fillets) & 9.14 & 12.49 & 23.63 & 9.23 & 8.13 & -5.22 & -11.95 \\
\hline Sub & & 18212.59 & 16972.14 & 17136.97 & 15048.91 & 14652.29 & $\begin{array}{r}-5.40 \\
\end{array}$ & -2.64 \\
\hline Lainn & & 45.35 & \begin{tabular}{|r|}
51.93 \\
\end{tabular} & 50.28 & 23.64 & 28.10 & -16.01 & 18.84 \\
\hline Tota & & 18257.94 & |17024.07 & 17187.24 & 15072.55 & 14680.39 & \begin{tabular}{|l|}
-5.43 \\
\end{tabular} & -2.60 \\
\hline
\end{tabular}

Ekspor udang beku (frozen shrimps), gurita (octopus), dan sotong (cuttle fish) merupakan ekspor terbesar Indonesia ke UE. Tren untuk sebagian besar produk ikan Indonesia di pasar UE positif dengan pertumbuhan terbesar yaitu ikan filet beku (frozen fish fillets) sebesar 54,88\% dan ikan todak beku (frozen swordfish) sebesar 54,38\%. Untuk udang beku, pertumbuhannya menurun sebesar $14.76 \%$ di tahun 2016 dikarenakan masalah kandungan antibiotik yang terdapat dalam produksinya.

\section{Hambatan untuk Ekspor ke Pasar Uni Eropa}

Daya saing subsektor di Indonesia sangat tergantung pada sejauh mana kedua hambatan untuk akses ke pasar Uni Eropa dapat dimitigasi. Menurut David Ricardo (Hady, 2001) bahwa perdagangan dapat dilakukan oleh negara yang tidak memiliki keunggulan absolut pada kedua komoditi yang diperdagangkan dengan melakukan spesialisasi produk. Indonesia bisa mengembangkan spesialisasi produk perikanan untuk mengatasi hambatan yang ada di pasar Uni Eropa.

Ada dua hambatan utama untuk ekspor ke pasar Uni Eropa, yaitu tarif 
impor dan standar keamanan pangan. Kedua aspek tersebut dibahas secara singkat di bagian ini.

\section{a. Hambatan Tarif Uni Eropa}

Bea masuk dan berbagai jenis tarif lainnya dalam perdagangan internasional sangat lazim digunakan. Tarif bea masuk produk perikanan ke negara-negara Uni Eropa berkisar antara 0\%-21\%. Namun demikian, UE sebagai kelompok negara maju juga memberikan skema Generalized System of Preferences (GSP) kepada negara-negara berkembang guna memperluas akses pasar ke negaranegara Uni Eropa. GSP Uni Eropa memberikan akses masuk dengan memberikan pengurangan tarif bea masuk bagi produk-produk yang diimpor dari negara penerima GSP. GSP termasuk tarif preferensi yaitu tarif General Agreement on Tariff and Trade (GATT) yang persentasinya diturunkan yang diberlakukan oleh negara terhadap komoditi yang diimpor dari negara-negara lain tertentu karena adanya hubungan khusus antara negara pengimpor dengen negara pengekspor.

Total pos tarif produk perikanan di UE sebanyak 1.166 pos tarif. UE masih memberlakukan sebagian besar pos tarif perikanan dengan tarif relatif tinggi sebesar 10-20\%. Sedangkan tarif yang masih tinggi sebesar 20$26 \%$ masih terdapat sebanyak 80 pos tarif.

Tabel 4.

Rekap Tarif MFN dan GSP Uni Eropa

\begin{tabular}{|l|r|l|r|}
\hline \multicolumn{1}{|c|}{ Tarif MFN } & Jumlah & \multicolumn{1}{c|}{ Tarif GSP } & Jumlah \\
\hline 0 & 83 & 0 & 105 \\
\hline$>0-5$ & 22 & $>0-5$ & 275 \\
\hline$>5-10$ & 295 & $>5-10$ & 351 \\
\hline$>10-20$ & 686 & $>10-20$ & 229 \\
\hline$>20-26$ & 80 & $>20$ & 36 \\
\hline Jml total PT & $\mathbf{1 1 6 6}$ & Jml total PT & $\mathbf{9 9 6}$ \\
\hline
\end{tabular}

Sumber: Data Diolah, Puska KPI Kemendag, 2015
Dari total pos tarif perikanan di UE, sebanyak 996 pos tarif mempunyai tarif preferensi GSP dengan besar tarif 0\% sejumlah 105 PT dan yang masih memiliki tarif tinggi antara 10-20\% sebanyak 229 PT.

Tarif impor untuk tuna telah banyak diperdebatkan karena Indonesia menghadapi tarif impor yang lebih tinggi dibandingkan dengan negara-negara lain yang memasok tuna ke Uni Eropa, terutama untuk produk tuna kaleng (20-25\%). Tarif ini juga diterapkan pada impor dari negara-negara Asia lainnya seperti Vietnam dan Filipina. Negara-negara seperti Fiji dan Papua Nugini telah menandatangani Perjanjian Kemitraan Ekonomi (EPA) dengan Uni Eropa dan dengan demikian menikmati tarif relatif rendah untuk tuna dan produk ikan lainnya. Pada saat ini, Indonesia berada di bawah Sistem Preferensi Umum (GSP) sistem di Uni Eropa. Namun, sebagai status semua negara sedang ditinjau, di masa depan mereka mungkin dihadapkan dengan tarif yang lebih tinggi. Sebuah contoh dari konsekuensi dari tarif impor yang lebih tinggi adalah industri udang Thailand yang kehilangan status istimewa untuk pasar Uni Eropa pada tahun 2000. Akibatnya, ekspor ke Uni Eropa turun drastis sementara ekspor ke AS meningkat pesat. Ekspor udang ke Uni Eropa hanya sedikit pulih setelah Tsunami pada tahun 2004 ketika Thailand kembali status preferensinya. Masalah utama dengan tarif impor adalah bahwa prosedur untuk memerangi kasus melawannya sering lama dan lambat.

\section{b. Hambatan Non Tarif Uni Eropa}

Komisi Eropa memiliki kebijakan dalam memenuhi konsumsi produk perikanan atau makanan berbasis pada perlindungan konsumen tingkat tinggi dengan memperhatikan lima 
komponen kebijakan umum dalam impor makanan (Direktorat Pemasaran Luar Negeri, 2006). Kelima komponen dapat diuraikan sebagai berikut: Standar pemasaran dan informasi konsumen, organisasi dari eksportir/produsen, Interbranch organisasi dan persetujuan, harga dan intervensi harga serta perdagangan dengan negara ketiga, regulasi yang berkaitan dengan kebijakan non tarif seperti standar mutu dan keamanan pangan dirangkum dalam Tabel 5.

Tabel 5.

Regulasi yang Berkaitan dengan Kebijakan Non Tarif

\begin{tabular}{|c|c|c|}
\hline \\
\hline $\begin{array}{c}\text { Tahun } \\
\text { Dikeluarkan }\end{array}$ & Kebijakan & Keterangan \\
\hline 1992 & $\begin{array}{l}\text { Regulation (EC) No 3760/92 tentang } \\
\text { Kebijakan Umum Perikanan (Common } \\
\text { Fisheries Policy) }\end{array}$ & $\begin{array}{l}\text { Tidak efektif dikarenakan tidak ada } \\
\text { kecocokan antara usaha perikanan dengan } \\
\text { sumber daya yang tersedia. }\end{array}$ \\
\hline 2001 & $\begin{array}{l}\text { EC No 466/2001 tanggal } 8 \text { Maret } 2001 \\
\text { Tentang Taraf Maksimum bagi Pencemar } \\
\text { Tertentu dalam Bahan Pangan }\end{array}$ & $\begin{array}{l}\text { Diantaranya mengatur taraf timbal, } \\
\text { kadmium, dan raksa dalam vahan pangan. }\end{array}$ \\
\hline 2002 & $\begin{array}{l}\text { EC No } 178 / 2002 \text { tanggal } 28 \text { Januari } 2002 \\
\text { Tentang Prinsip Umum dan Persyaratan } \\
\text { Hukum Pangan, Pembentukan Otoritas } \\
\text { Keamanan Pangan Eropa dan Penetapan } \\
\text { Prosedur yang Terkait dengan Keamanan } \\
\text { Pangan }\end{array}$ & $\begin{array}{l}\text { Kunci pokok regulasi standar mutu dan } \\
\text { keamanan pangan Uni Erope yang } \\
\text { berbasis perlindungan konsumen tingkat } \\
\text { tinggi, kepedulian terhadap hewan dan } \\
\text { juga lingkungan. }\end{array}$ \\
\hline 2004 & $\begin{array}{l}\text { EC No 852/2004 Tanggal } 29 \text { April } 2004 \\
\text { tentang Higien Bahan Pangan }\end{array}$ & $\begin{array}{l}\text { Regulasi ini merupakan ratifikasi SPS dari } \\
\text { WTO dan standar keamanan pangan } \\
\text { internasional yang termuat dalam Codex } \\
\text { Alimentarius. Persyarataan umum } \\
\text { produksi primer, persyaratan teknis, } \\
\text { HACCP, pendaftaran'pengakuan usaha } \\
\text { makanan, petunjuk nasional untuk praktek } \\
\text { yang baik. }\end{array}$ \\
\hline 2004 & $\begin{array}{l}\text { EC No 853/2004 Tanggal } 29 \text { April } 2004 \\
\text { Tentang Peraturan Kesehatan Spesifik untuk } \\
\text { Pangan Asal Hewan }\end{array}$ & $\begin{array}{l}\text { Aturan higienis yang spesifik untuk } \\
\text { makanan dari asal hewan (pengakuan dari } \\
\text { perusahaan, kesehatan, dan identifikasi } \\
\text { penandaan, impor, informasi rantai } \\
\text { pangan) }\end{array}$ \\
\hline 2004 & $\begin{array}{l}\text { EC No 854/2004 Tanggal } 29 \text { April tentang } \\
\text { aturan khusus bagi organisasi pengawasan } \\
\text { resmi untuk produk asal hewan yang } \\
\text { dikonsumsi manusia }\end{array}$ & $\begin{array}{l}\text { Aturan secara rinci untuk organisai dari } \\
\text { kontrol resmi pada produk asal hewan }\end{array}$ \\
\hline 2004 & $\begin{array}{l}\text { EC No } 882 / 2004 \text { tanggal } 29 \text { April } 2004 \\
\text { tentang pengawasan resmi guna menjamin } \\
\text { verifikasi terhadap pelaksanaan Undang- } \\
\text { Undang Pangan dan Pakan, dan peraturan } \\
\text { kesehatan hewan dan kesejahteraan hewan. }\end{array}$ & $\begin{array}{l}\text { Sertifikasi hewan, sesuai dengan aturan } \\
\text { Uni Eropa. }\end{array}$ \\
\hline 2005 & $\begin{array}{l}\text { EC No } 2073 / 2005 \text { tanggal } 15 \text { November } \\
2005 \text { tentang kriteria mikrobiologi untuk } \\
\text { bahan pangan. }\end{array}$ & \\
\hline
\end{tabular}

Regulasi-regulasi yang nantinya dapat menjadi hambatan perdagangan bagi impor produk-produk pangan, termasuk di dalamnya komoditi perikanan antara lain yaitu :

a) EC No. 178 tahun 2002 tentang persyarat-an mutu undang-undang pangan serta prosedur keamanan pangan. Salah satu kebijakan yang cukup signifikan mempengaruhi perkem-bangan impor pangan Uni Eropa yaitu diterapkannya Rapid Alert System for Food and Feeds (RASFF). Pengaruh ini berdampak kepada peredaran produk negara eksportir di Uni Eropa. Total kasus alert untuk produk yang berasal dari Indonesia meningkat dari tahun 2002 sebanyak 39 kasus menjadi 43 kasus pada tahun 2006.

b) EC No. 852 tahun 2004 tentang higienis/ kebersihan bahan pangan merupakan aplikasi dari EC No. 178 tahun 2002 yang menitikberatkan pada penerapan prinsip HACCP dan good practice, EC No. 853 tahun 2004 tentang peraturan khusus untuk keamanan bahan baku mengimple-mentasikan konsep "from farm to fork" yang menekankan aplikasi keamanan pangan sejak penangkap-an hingga proses pengolahan.

c) EC No. 466 tahun 2001 tentang taraf maksimum bagi pencemar tertentu dalam bahan pangan diantaranya mengatur taraf maksimum bahan pencemar yang diperbolehkan dalam bahan pangan. Bahan pencemar yang dimaksud diantara-nya berupa timbal $(P b)$, kadmium $(C d)$, dan raksa $(H g)$. Batas maksimum yang diperbolehkan dalam krustasea (udang) untuk $\mathrm{Pb}$ sebesar 0,5 mg/kg (Ditjen P2HP, 2007).

Kebijakan-kebijakan tersebut nantinya dapat menjadi hambatan perdagangan bagi impor produk-produk pangan, termasuk di dalamnya komoditi perikanan. Uni Eropa memberlakukan regulasi ini dengan terlebih dahulu memberikan pembuktian ilmiah kepada organisasi perdagangan dunia (WTO). Regulasi yang dikeluarkan oleh Komisi Eropa (European Commision) secara umum diberlakukan dua puluh hari setelah diterbitkan dalam Official Journal (OJ). European Commision adalah lembaga eksekutif pemerintah Uni Eropa yang bertanggungjawab terhadap pelaksanaan peraturan Uni Eropa kepada dewan dan parlemen Eropa, termasuk di dalamnya 
peraturan mengenai pengawasan mutu dan keamanan pangan. Komisi ini terdiri dari perwakilan tiap-tiap negara anggota (Europa, 2007).

\section{Standar Keamanan Pangan}

Tingginya tingkat standar keamanan pangan di Uni Eropa dibandingkan dengan tingkat standar di pasar seperti Amerika Serikat dan Jepang merupakan penghalang bagi eksportir sebagai contoh, untuk budidaya udang, Uni Eropa menuntut agar setiap negara pengekspor memiliki label produk dari setiap tambak udang untuk menjamin ketertelusuran penuh dan tidak ada obat-obatan terlarang yang digunakan selama siklus produksi. Jika karena alasan tertentu rantai pasokan lokal di negara-negara penghasil udang tidak bisa memenuhi persyaratan ini atau tidak dapat lulus tes, ini mungkin merupakan alasan untuk ekspor ke negara-negara lain sebagai gantinya. Indonesia dalam beberapa tahun terakhir, dihadapkan dengan penolakan oleh Uni Eropa (dan Amerika Serikat dan Jepang) berdasarkan adanya antibiotik, sebagai gantinya eksportir mengalihkan fokus mereka ke pasar lain dengan standar kesehatan kurang ketat daripada di Uni Eropa. Hambatan ini dapat diselesaikan dengan capacity building, produsen dilatih untuk memenuhi standar Uni Eropa.

Uni Eropa memerlukan ketersediaan sertifikat hasil tangkapan untuk setiap ikan yang diimpor di Uni Eropa. Sertifikat ini merupakan bagian dari peraturan Uni Eropa tentang Illegal, Unreported and Unregulated (IUU) fishing. Seperti banyak perikanan di negara berkembang terdiri dari kapal kecil yang sering tidak benar terdaftar dan sebagian besar di operasikan oleh nelayan tidak berpendidikan, pengenalan sertifikat hasil tangkapan telah terbukti menjadi penghalang bagi ekspor ke Uni Eropa. Namun, dilaporkan bahwa sebagian besar perikanan utama sekarang telah mendaftarkan semua kapal dan menerapkan kebijakan baru yang membantu nelayan dan eksportir memberikan dokumen yang diperlukan untuk ekspor ke pasar Uni Eropa.

\section{Analisis Daya Saing Indonesia di Pasar Uni Eropa}

Apabila kita lihat berdasarkan analisis Pangsa Pasar Konstan (Constant Market Share Analysis /CMSA), kita dapat mengetahui faktor penyebab tumbuhnya ekspor suatu negara ke negara mitra dagangnya.

Tabel 6.

Analisis Constant Market Share untuk Ekspor ke Uni Eropa

\begin{tabular}{cccr}
\hline $\begin{array}{c}\text { Negara Tujuan } \\
\text { Ekspor }\end{array}$ & World Demand & Product Effect & Competitiveness \\
\hline Uni Eropa & $152,340.20$ & $113,014.34$ & $147,266.46$ \\
& Sumber: Hasil Analisis & CMSA &
\end{tabular}

Tabel 6 menunjukkan analisis CMSA Indonesia di pasar Uni Eropa pada tahun 2013-2014. Pertumbuhan ekspor produk perikanan Indonesia di pasar Uni Eropa lebih banyak didorong oleh faktor permintaan dunia. Hal ini menunjukkan bahwa ekspor produk perikanan Indonesia didorong oleh adanya permintaan dari dunia. Tingginya nilai faktor permintaan dunia mengindikasikan bahwa pertumbuhan nilai ekspor produk perikanan Indonesia yang terjadi pada tahun 2013-2014 paling banyak disebabkan oleh tingginya pertumbuhan permintaan total dunia sehingga permintaan dunia untuk produk perikanan pun mengalami peningkatan.

Produk perikanan Indonesia memiliki angka daya saing yang cukup tinggi dibandingkan nilai efek komposisi produk, yaitu sebesar US\$ 147.266,46. Angka yang tinggi tersebut menandakan bahwa produk perikanan Indonesia memiliki daya saing yang tinggi di pasar Uni Eropa dibadingkan perubahan pola 
konsumsi masyarakatnya. Tingginya angka competitiveness juga menggambarkan apabila diasumsikan permintaan dunia sebesar 0 , maka produk perikanan Indonesia masih memiliki daya saing yang tinggi. Hasil ini sejalan dengan konsep dari Salvatore (1997) dimana Indonesia dapat memperoleh manfaat dari perdagangan internasional jika melakukan spesialisasi produksi dan memproduksi perikanan tersebut dengan lebih efisien.

Tabel 7.

Matriks Prioritas Produk Potensial ke EU

\begin{tabular}{|c|c|c|c|c|c|c|c|c|}
\hline HS & Description & $\begin{array}{l}\text { World } \\
\text { Demand }\end{array}$ & $\begin{array}{l}\text { Product } \\
\text { Effect }\end{array}$ & Competitiveness & Ekspor & MFN & Rank & Pesaing \\
\hline 6052 & Prepared or preserved & $9.844,27$ & 19.277,84 & 2.784,89 & 100.052 & 0 & & 3 VVNM (2), THL (4) \\
\hline 3057 & Octopus, frozen, dried, & $6.658,39$ & $1.704,37$ & 642,24 & 26.675 & 4,2 & & 7 VNM (10), THL (13) \\
\hline 13023 & Mucilages \& thickeners & 166,02 & $2.194,79$ & 16,19 & 24.884 & 0 & & 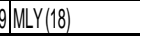 \\
\hline
\end{tabular}

Tabel 7 memperlihatkan prioritas produk perikanan Indonesia yang potensial untuk masuk ke pasar di kawasan Uni Eropa beserta negara pesaing untuk produk tersebut. Produk perikanan Indonesia yang potensial adalah HS 160521 (Prepared or preserved Shrimps and prawns : Not in airtight container), HS 030759 (Octopus, frozen, dried, salted or in brine), dan HS 130239 (Mucilages \& thickenerness, modified or not, derived from vegetable products). Negara pesaing untuk produk-produk tersebut adalah Vietnam, Thailand, dan Malaysia.

\section{Analisis Export Product Dynamic (EPD)}

Hasil analisis Export Product Dynamic (EPD) di pasar Uni Eropa menunjukkan sebanyak 165 produk perikanan Indonesia di posisi rising star (winner in increasing market), 18 produk pada posisi lost opportunity, 14 produk pada posisi winner in declining market dan sebanyak 10 produk pada posisi Loser (loser in declining market). Produk pada rising star menunjukkan produk tersebut memiliki pertumbuhan pangsa ekspor yang bernilai positif di pasar Uni Eropa dan merupakan komoditi yang kompetitif serta dinamis di pasar Uni Eropa. Sedangkan posisi lost opportunity menunjukkan perolehan ekspor mengalami penurunan tetapi produk masih kompetitif di pasar Uni Eropa karena permintaan produk tersebut masih tinggi di negara tersebut. Produk Perikanan Indonesia yang mengalami lost opportunity adalah HS 030246 (Fish nes, salted and in brine, but not dried or smoked), HS 030273 (Carp, live), HS030326 (Tunas nes, fresh or chilled, excluding heading No 03.04,livers and roes), HS 030365 (Salmonidae, nes, frozen, excluding heading No 03.04, livers and roes), HS 030569 (Fish nes, smoked including fillets) dan HS 030721 (Crustaceans nes, not frozen,in shell or not,including boiled in shell).

\section{Gambar 3. Kuadran EPD Produk Indonesia di Pasar Uni Eropa}

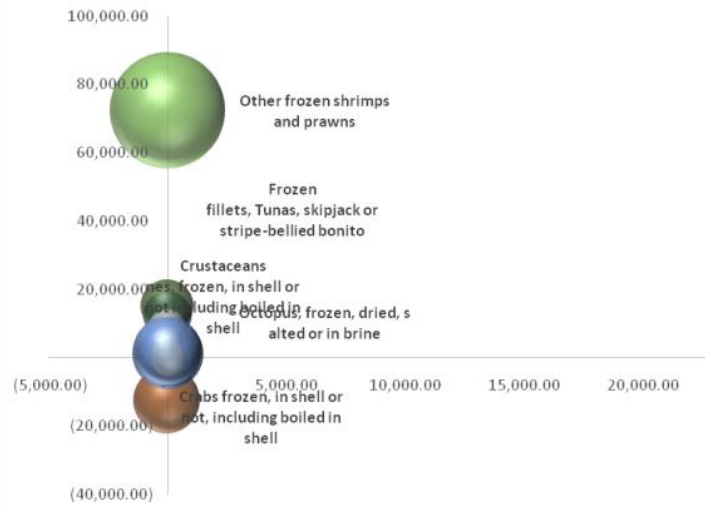

Sumber : Trade Map, 2015 (diolah)

\section{Kesimpulan dan Rekomendasi}

Kesimpulan dari penelitian ini antara lain sebagai berikut:

a. Tarif Uni Eropa yang cukup tinggi berkisar diantara $0-21 \%$ diantara negara-negara potensial lainnya mengalami perubahan terutama bagi negara berkembang dengan diterapkannya skema GSP yang diberlaku- 
kan juga bagi negara Indonesia untuk komoditas perikanan.

b. Kebijakan non tarif yang dirasakan mulai memberatkan pemerintah dan pengusaha perikanan yaitu terkait standar mutu dan pangan dengan dikeluarkannya EC No. 178 tahun 2002, EC No. 852 tahun 2004, EC No. 853 tahun 2004, EC No. 854 tahun 2004, EC No. 882 tahun 2004, serta EC No. 2073 tahun 2005 dengan basis perlindungan konsumen tingkat tinggi.

c. Produk Kelautan dan Perikanan Indonesia berkembang pesat dalam 3 tahun terakhir ini dan merupakan produk potensial untuk dikembangkan di Pasar Uni Eropa.

d. Penguasaan pasar Uni Eropa perlu mencermati kebijakan non tarif Uni Eropa yang masih sangat ketat.

e. Berdasarkan hitungan Constant Market Share Analysis (CMSA), Pertumbuhan ekspor produk perikanan Indonesia di pasar Uni Eropa lebih banyak didorong oleh faktor permintaan dunia. Hal ini menunjukkan bahwa ekspor produk perikanan Indonesia didorong oleh adanya permintaan dari dunia.

f. Produk perikanan Indonesia yang potensial adalah HS 160521 (Prepared or preserved Shrimps and prawns : Not in airtight container), HS 030759 (Octopus, frozen, dried, salted or in brine), dan HS 130239 (Mucilages \& thickeners nes, modifid or not,derivd from vegetable products). Negara pesaing untuk produk-produk tersebut adalah Vietnam, Thailand, dan Malaysia.

g. Hasil analisis Export Product Dynamic (EPD) di pasar Uni Eropa menunjukkan sebanyak 165 produk perikanan Indonesia di posisi rising star (winner in increasing market), 18 produk pada posisi lost opportunity (loose market opportunity), 14 produk pada posisi winner in declining market dan sebanyak 10 produk pada posisi Loser (loser in declining market).

Rekomendasi kebijakan yang bisa diusulkan adalah sebagai berikut:

a. Indonesia perlu menegosiasikan untuk hambatan tarif dan non tarif sehingga produk Indonesia dapat memasuki pasar Uni Eropa lebih mudah.

b. Indonesia perlu menyusun kerangka kebijakan strategi promosi ikan dengan mengedepankan image Indonesia di pasar Uni Eropa.

c. Dalam rangka memenuhi permintaan impor Uni Eropa diharapkan pemerintah maupun pengusaha perikanan mampu mengetahui dengan cepat perkembangan isu perdagangan. Salah satunya yaitu mengakses dengan baik fasilitas help desk online yang dikeluarkan Uni Eropa untuk membantu negara partner dagang dalam mengakses informasi mengenai pasar Uni Eropa. Selain itu, perlu adanya analisis pasar yang cukup akurat untuk bisa mengetahui market share Indonesia saat ini maupun beberapa tahun mendatang.

d. Indonesia perlu melakukan konsolidasi kebijakan publik secara makro dengan membantu pemulihan pasar perikanan dunia dengan meningkatkan koordinasi dengan FAO dan organisasi internasional lainnya.

\section{Daftar Pustaka}

BPS, 2015, Ekspor dan Impor. Badan Pusat Statistik. Jakarta

CIA, 2015, The World Factbook. Report dari Central Intelligence Agency (CIA). Diunduh tanggal 02 Desember 2015

Dahuri, H. Rokhmin, 2002, Paradigma Baru Pembangunan Indonesia Berbasis Kelautan. Orasi Ilmiah, Fakultas Perikanan dan Ilmu Kelautan, Institut Pertanian Bogor

Ditjen P2HP, 2007, Peningkatan Nilai Tambah Ikan dan Olahannya Melalui 
Teknologi Penangangan dan Pengolahan. Direktorat jenderal Pengolahan dan Pemasaran Hasil Perikanan (Ditjen P2HP). Jakarta

Fugazza, Marco, 2017, Fish Trade and Policy: A Primer on Non-Tariff Measures. UNCTAD Research Paper No.7, United Nations Conference on Trade and Development

Hady, Hamdy, 2001, Teori dan Kebijakan Perdagangan Ekonomi Internasional. Ghalia Indonesia, Jakarta

Kee, Hiau Looi, Alessandro Nicita and Marcelo Olarreaga, 2004, Import demand elasticities and trade distortions. Working Paper 3452 of World Bank Policy Research

Painte, E. Riri, 2008, Analisis Pengaruh Hambatan Tarif dan Non Tarif di Pasar Uni Eropa Terhadap Ekspor Komoditas Udang Indonesia. Skripsi Manajemen Bisnis dan Ekonomi Perikanan-Kelautan, Fakultas Perikanan dan Ilmu Kelautan. Institut Pertanian Bogor

Pusparani, Tika Nur, 2015, The Impact of Food Safety Measures Implementation on Indonesia's Exports of Fisheries. Research Paper of The Hague, The Netherlands

Salvatore, Dominick, 1997, Ekonomi Internasional, alih bahasa oleh Haris Munandar edisi 5 cetak 1. Erlangga, Jakarta

Ur, Linda Norum, 2014, Tariff Rate Quotas - Free Trade or Non-Tariff Barriers? The Case of Norwegian Seafood Exports to the EU. Thesis for the
Degree Master of Philosophy in Economics, University of Oslo

$\underline{\text { Website }}$

EC, 2010, Trade Policy. Report dari European Commission. Diunduh tanggal 02 Desember 2015 dari http://ec.europa.eu/trade/policy/countri es-and-regions/countries/indonesia/.

Euromonitor, 2013, International Countries Market Research. Report Data dari Euromonitor. Diunduh tanggal 03 Desember 2015 dari http://www.euromonitor.com.

Euromonitor, 2015, International Countries Market Research. Report Data dari Euromonitor. Diunduh tanggal 03 Desember 2015 dari http://www.euromonitor.com.

Europa, 2007, SFC Support Portal. Report dari Europa. Diunduh tanggal 02 Desember $2016 \quad$ dari https://ec.europa.eu/sfc/en/2007.

Eurostat, 2015, European Statistics. Report Data dari Eurostat. Diunduh 03 Desember 2015 dari http://ec.europa.eu/eurostat/data/databa se.

Trademap, 2015, Trade Statistics for International Business Development. Report Data dari Trademap. Diunduh tanggal 03 Desember 2015 dari http://www.trademap.org.

UNComtrade, 2015, Commodity Trade Statistics Database. Report Data dari United Nations Commodity Trade. Diunduh tanggal 03 Desember 2015 dari http://www.comtrade.un.org. 